\title{
Epidemiological and clinical profile of patients with pressure injury after spinal cord trauma
}

\section{Perfil epidemiológico e clínico de pacientes com lesão por pressão após trauma raquimedular}

\section{Perfil epidemiológico y clínico de pacientes con lesión por presión después de una lesión medular}

\author{
Fabio Conceição dos Santos ${ }^{1, *}$, Marcelo Williams Oliveira de Souza ${ }^{2}$, Odenilce Vieira Pereira ${ }^{3}$, \\ Ingrid Magali de Souza Pimentel ${ }^{2}$, Aline Maria Pereira Cruz Ramos ${ }^{4}$
}

ORCID IDS

Santos FC (D) https://orcid.org/0000-0002-1191-7063

Souza MWO (D) https://orcid.org/0000-0002-1907-7687

Pereira OV (iD https://orcid.org/0000-0002-4698-6413

Pimentel IMS (D) https://orcid.org/0000-0003-1820-5496

Ramos AMPC (D) https://orcid.org/0000-0001-8812-2923
HOW TO CITE

Santos FC; Souza MWO; Pereira OV; Pimentel IMS; Ramos AMPC. Epidemiological and clinical profile of patients with pressure injury after spinal cord trauma. ESTIMA, Braz. J. Enterostomal Ther., 17, 2019: e2719. https://doi.org/10.30886/estima.v17.773_IN

\begin{abstract}
Introduction: The prevalence of pressure injury (PI) varies with the clinical environment and the characteristics of the patient, thus, patients with spinal cord trauma (SCT) are configured among those with greater predisposition to the length of hospitalization, presenting impaired movements and sensitivity. Objective: To know and analyze the prevalence of pressure injury in patients suffering from spinal cord trauma hospitalized in a reference hospital. Method: Cross-sectional, retrospective study. The sample consists of medical records of patients with spinal cord trauma who presented pressure injury during hospitalization in a reference hospital in the state of Pará, Brazil, during the period from 2013 to 2016. Results: We analyzed 565 medical records of patients with spinal cord, with the prevalence of PI in of $8 \%$ of patients with SCT. The mean age was 37 years, with $80 \%$ composed of men, with an average length of hospitalization of 66.68 days. The majority presented as etiology of spinal cord injury accidents by firearm and fall, with 32 and 30\% respectively. Spinal cord injury was predominant in the thoracic region (50\%), where 64\% had paraplegia as sequelae and $86 \%$ presented pressure injury in the sacral region. Conclusion: It was possible to identify the prevalence of PI in patients with SCT and to know its behavior. Thus, the availability of data helped to demonstrate the occurrence of PI as a complication in patients with SCT during hospitalization, and can serve as a basis for the allocation of preventive resources and measures, as well as further studies on the theme.
\end{abstract}

DESCRIPTORS: Spine; Pressure injury; Epidemiology; Enterostomal therapy.

\section{RESUMO}

Introdução: A prevalência de lesão por pressão (LP) varia com o ambiente clínico e as características do paciente, assim, pacientes com traumatismo raquimedular (TRM) configuram-se entre aqueles com maior predisposição diante do tempo de internação, apresentando movimentos e sensibilidade prejudicados. Objetivo: Conhecer e analisar a prevalência de LP em pacientes vítimas de TRM internados em um hospital de referência. Método: Estudo transversal, retrospectivo. A amostra compõe-se de prontuários de pacientes com TRM que apresentaram LP durante a internação em um hospital de referência no estado do Pará, Brasil, durante

1.Centro Universitário do Estado do Pará - Programa de Residência Multiprofissional em Neurologia - Belém/PA - Brazil.

2.Universidade do Estado do Pará - Escola de Enfermagem Magalhães Barata - Departamento de Enfermagem Hospitalar - Belém/PA - Brazil.

3.Unidade Hospitalar João de Barros Barreto - Departamento de Enfermagem - Belém/PA - Brazil.

4. Universidade Federal do Pará - Faculdade de Enfermagem - Belém/PA - Brazil.

*Correspondence author: fabiosantos-166@hotmail.com

Received: Jun. 23, 2019 | Accepted: Nov. 13, 2019 
o período de 2013 a 2016. Resultados: Analisaram-se 565 prontuários de pacientes com trauma raquimedular, com a prevalência de lesão por pressão em de $8 \%$ dos pacientes com TRM. A média de idade foi de 37 anos, com 80\% composta por homens, com tempo médio de internação de 66,68 dias. A maioria apresentou como etiologia da lesão medular os acidentes por arma de fogo e queda, com 32 e 30\% respectivamente. A lesão medular foi predominante na região torácica (50\%), onde 64\% tiveram a paraplegia como sequela e 86\% apresentaram LP em região sacral. Conclusão: Foi possível identificar a prevalência de lesão por pressão em pacientes com traumatismo raquimedular e conhecer seu comportamento. Desse modo, a disponibilização dos dados ajudou a demostrar a ocorrência de LP como complicação em pacientes com TRM durante a internação, podendo servir como base para a alocação de recursos e medidas preventivas, como também estudos posteriores sobre a temática.

DESCRITORES: Coluna vertebral; Lesão por pressão; Epidemiologia; Estomaterapia.

\section{RESUMEN}

Introducción: La prevalencia de la lesión a presión varía según el entorno clínico y las características del paciente, por lo tanto, los pacientes con Trauma de la Médula Espinal (TME) se configuran entre aquellos con mayor predisposición a la duración de la hospitalización, presentando movimientos y sensibilidad deteriorados. Objetivo: Conocer y analizar la prevalencia de lesión por presión en pacientes que sufren de traumatismo de la médula espinal hospitalizados en un hospital de referencia. Método: Estudio transversal retrospectivo. La muestra consiste en registros médicos de pacientes con traumatismo de la médula espinal que presentaron lesión por presión durante la hospitalización en un hospital de referencia en el estado de Pará, Brasil, durante el período de 2013 a 2016. Resultados: Analizamos 565 registros médicos de pacientes con médula espinal, con la prevalencia de Lesión por Presión en pacientes con traumatismo de la médula espinal del 8\%. La edad media fue de 37 años, con un 80\% compuesto por hombres, con una duración media de hospitalización de 66,68 días. La mayoría se presentó como etiología de accidentes de lesión de la médula espinal por arma de fuego y caída, con 32 y 30\% respectivamente. La lesión de la médula espinal fue predominante en la región torácica (50\%), donde el 64\% tenía paraplejia como secuencias y el 86\% presentó lesión por presión en la región sacral. Conclusión: Fue posible identificar la prevalencia de lesión por presión en pacientes con traumatismo de la médula espinal y conocer su comportamiento. Por lo tanto, la disponibilidad de datos ayudó a demostrar la aparición de LP como una complicación en pacientes con TME durante la hospitalización, y puede servir de base para la asignación de recursos y medidas preventivas, así como más estudios sobre el tema.

DESCRIPTORES: Columna vertebral; Lesión por presión; Epidemiología; Estomaterapia.

\section{INTRODUCTION}

The increase in life expectancy is also due to advances in healthcare, enabling the survival of patients with severe, chronic and debilitating diseases, which results in longer length of stay and the appearance of complications, such as pressure injury $(\mathrm{PI})^{1}$. The occurrence of this lesion varies according to the clinical environment and patient characteristics, with greater frequency in acutely hospitalized patients or in long hospitalizations².

Thus, patients with spinal cord injury (SCI) are among those with a greater predisposition to PI during the prolonged period of hospitalization, because they remain bedridden with impaired movements and sensitivity. Furthermore, SCI can lead to other complications and indirect impairments, such as autonomic dysreflexia, postural hypotension, heterotopic ossification, contractures, deep venous thrombosis, painful syndromes (traumatic pain, nerve root pain, among others), osteoporosis and kidney stones ${ }^{3}$.

In Brazil, it is estimated that there are about 40 new cases of SCI per million inhabitants, with a total of six to eight thousand cases per year, among which $80 \%$ of the victims are men, representing a high cost to the health system. It is noteworthy that the data are not accurate due to the non-obligation of notification ${ }^{4}$.

In hospitalized patients, the development of PI is a major health problem, as it can cause physical discomfort, increased risk of additional complications, prolonged hospitalization and increased costs related to treatment ${ }^{5}$.

According to the National Pressure Ulcer Advisory Panel (NPUAP), a pressure injury is a localized damage in the skin and/or underlying soft tissue usually over a bone prominence or related to the use of a medical device. The lesion results from the result of intense and/or prolonged pressure in combination with shear, and may also be affected by microclimate, nutrition, perfusion, comorbidities and their condition, besides characterizing a negative indicator of the quality of care ${ }^{2}$.

It is a multifactorial lesion whose assistance is a challenge for the nursing team, considering the complexity of care. However, this category has implemented systematic preventive measures in protocols based on international guidelines 5 . According to this, health service managers have been concerned with the theme related to the occurrence 
of this event, due to ethical, social, legal and financial aspects, which determines implementing prevention measures and quality indicators related to this grievance, given that the reduction of PI risk is one of the goals within the Brazilian National Patient Safety Program6.

Therefore, describing and analyzing the occurrence of $\mathrm{PI}$ in patients with SCI is essential in order to contribute to epidemiological estimates, so that there is an outline of future interventions capable of reducing its occurrence and complications, in addition to reducing the costs with the treatment of PI when installed. Thus, this research becomes a pioneer in our region and relevant to the extent that it can support healthcare practices as a way to prevent and/or minimize the appearance of PI in patients with SCI.

Hence, considering the justification for the scientific studies of the presented problem, a concern about this research emerged, which was guided by the following question: what is the occurrence of pressure injury in patients with spinal cord injury in a reference hospital?

\section{OBJECTIVE}

To know and analyze the prevalence of pressure injury in patients with spinal cord injury admitted to a reference hospital in the state of Pará, Brazil.

\section{METHODS}

This is a cross-sectional, retrospective study. The study was conducted in an emergency hospital located in the metropolitan region of Belém, state of Pará, Brazil. This institution is a reference in the care of victims of trauma and burns, attending to medium and high complexity.

Data collection was conducted at the medical and statistical archive service of this hospital after authorization. Secondary data (finalized medical records) of patients who suffered accidents that resulted in spinal cord injury during the four-year period from January 2013 to December 2016 were used. Medical records of patients aged 18 to 80 years, diagnosed with SCI, who developed PI during hospitalization, were eligible. The medical records of patients under 18 and over 80 years of age, with PI at admission, and those outside the period established for the study were excluded. A total of 565 medical records were included in the study, of which 112 in 2013, 128 in 2014, 179 in 2015, and 146 in 2016.

For data collection, a form prepared by the authors with closed questions and the following variables was used: 1) sociodemographic: period of hospitalization, age, gender, place of birth and city of origin, discharge or death; 2) clinical data from the SCI: etiology, level of spinal cord injury, sequel; 3) PI data: time for first injury, number of injuries presented, affected regions, presence or not of infection and if there was, which was; 4) data on nursing care: preventive care, diagnosis and nursing care to the patient with PI.

Data were tabulated in Microsoft Office Excel 2016 software, submitted to descriptive statistics with calculation of the proposed variables (absolute and relative frequency, standard deviation and prevalence of PI in patients per year and period under study) in tables and graphs, with the software BioEstat 5.3. To identify the prevalence of PI, a mathematical calculation was performed: number of patients who presented PI in each year divided by the total number of patients with SCI per year, with each result multiplied by 100. In the same way, the prevalence during the period from 2013 to 2016 was calculated as: number of patients who presented PI from 2013 to 2016 divided by the total number of patients with SCI from 2013 to 2016, multiplying the final value by 100 . The data were interpreted and discussed with the findings in the literature, giving input to the content.

The study followed the guidelines established by Resolution No. 466 of December 2012 of the National Health Council. The project was approved by the Committee for Ethics and Research in Human Beings of the Centro Universitário do Estado do Pará - CESUPA, under opinion number 2.683.731 and CAAE 90029218.0.0000.5169.

\section{RESULTS}

The sociodemographic and clinical characteristics of the patients are presented in tables. From the total of 565 medical records surveyed, 50 (8.84\%) patients with SCI developed PI during hospitalization between January 2013 and December 2016. The annual data of this type of lesion, as well as its annual prevalence and during the period are shown below (Table 1). 
Table 1. Distribution of cases of spinal cord injury (SCl) and pressure injury (PI) after $\mathrm{SCl}$, according to the period, in patients treated at a reference hospital, from 2013 to 2016. Belém-PA, 2019.

\begin{tabular}{cccc}
\hline $\begin{array}{c}\text { Year of } \\
\text { occurence }\end{array}$ & SCl cases & No. of PI & $\begin{array}{c}\text { Prevalence } \\
\text { of PI }\end{array}$ \\
\hline 2013 & 112 & 6 & 5 \\
\hline 2014 & 128 & 13 & 10 \\
\hline 2015 & 179 & 14 & 7 \\
\hline 2016 & 146 & 17 & 11 \\
\hline Total & 565 & 50 & 8 \\
\hline
\end{tabular}

Source: Research data, 2019.

Table 2 shows that the mean age of the patients was $37.08( \pm 15.33)$ years, with a maximum age of 80 and a minimum of 18 years. The male gender predominated among the patients surveyed in relation to the female, with $40(80 \%)$ and $10(20 \%)$, respectively. It was observed that 21 patients (42\%) were from the metropolitan region of Belém and 29 (58\%) from the interior of the state. The mean length of stay was 66.68 days, with a maximum of 161 and a minimum of 5 days. The clinical outcome of most patients was: $44(88 \%)$ improved discharge and $6(12 \%)$ deaths from various causes, with emphasis on sepsis, ventilator-associated pneumonia, venous thromboembolism and other complications.

Regarding the clinical aspects of patients with SCI (Table 3), it was evidenced that 16 patients (32\%) had firearm-related accidents as the cause of trauma and 15 (30\%) had fall-related accidents. In relation to the body region that was most affected by trauma, the predominance was in the thoracic region with 24 cases (50\%), followed by the cervical region with 13 (26\%), and the lumbar region with 20 (10\%). It is known that impairment of the spinal cord level determines irreversible sequelae. In this study, 32 (64\%) evolved to paraplegia and 18 (36\%) to tetraplegia.

Regarding the characteristics of PIs (Table 4) related to appearance, risk factors, number of lesions, affected body region and presence of infection, the following data were evidenced: mean time of appearance was 19.32 days; among the risk factors, smoking associated with alcoholism was highlighted in 13 cases (26\%) of the sample, and 21 lesions (42\%) were associated with other comorbidities (loss of motor function and sensitivity, malnutrition, hypertension, fecal and urinary incontinence, among others). It is worth mentioning that 35 patients (70\%)
Table 2. Sociodemographic profile of patients with $\mathrm{SCl}$ who presented PI in a reference hospital, from 2013 to 2016. Belém-PA, 2019.

\begin{tabular}{|c|c|c|}
\hline Characteristics & $n=50$ & Freq. (\%) \\
\hline \multicolumn{3}{|l|}{ Gender } \\
\hline Male & 40 & 80 \\
\hline Female & 10 & 20 \\
\hline \multicolumn{3}{|l|}{ Place of birth } \\
\hline Pará & 50 & 100 \\
\hline Other state & 0 & 0 \\
\hline \multicolumn{3}{|l|}{ Cities of region } \\
\hline Metropolitan region & 21 & 42 \\
\hline Other cities & 29 & 58 \\
\hline $\begin{array}{l}\text { Mean length of hospitalization (maximum } \\
161 \text { days and minimum } 5 \text { days) }\end{array}$ & 66,68 & \\
\hline \multicolumn{3}{|l|}{ Clinical outcome } \\
\hline Improved dischare & 44 & 88 \\
\hline Death & 6 & 12 \\
\hline
\end{tabular}

Source: Research data, 2019

Table 3. Clinical aspects related to the $\mathrm{SCl}$ of investigated patients who presented $\mathrm{Pl}$ in a reference hospital, from 2013 to 2016. Belém-PA, 2019.

\begin{tabular}{|c|c|c|}
\hline Characteristics & $\mathrm{n}=50$ & Freq. (\%) \\
\hline Car accident & 3 & 6 \\
\hline Motorcycle accident & 7 & 14 \\
\hline Firearm accident & 16 & 32 \\
\hline Fall & 15 & 30 \\
\hline Shallow water diving & 2 & 4 \\
\hline Other & 7 & 14 \\
\hline \multicolumn{3}{|l|}{ Injury level } \\
\hline Cervical & 13 & 26 \\
\hline Thoracic & 25 & 50 \\
\hline Lumbar & 10 & 20 \\
\hline Cervicothoracic & 1 & 2 \\
\hline Thoracolumbar & 1 & 2 \\
\hline \multicolumn{3}{|l|}{ Presented sequel } \\
\hline Paraplegia & 32 & 64 \\
\hline Tetraplegia & 18 & 36 \\
\hline
\end{tabular}

Source: Research data, 2019.

developed only one PI, with a mean of around $1.68( \pm 1.16)$; in contrast, 7 patients (14\%) presented three PIs. As for the most affected body area, there was a predominance of the sacral region with 43 occurrences (86\%), followed by the calcaneus and occipital region with $3(6 \%)$ occurrences in each location. Regarding infection of the lesions, only 
Table 4. Characteristics related to PI of patients with SCI in a reference hospital, from 2013 to 2016. Belém-PA, 2019.

\begin{tabular}{|c|c|c|}
\hline Características & Freq. & $\%$ \\
\hline $\begin{array}{l}\text { Mean time for } 1 \text { st PI in days and standard deviation } \\
\text { Risk factor }\end{array}$ & $19.32 \pm 17.23$ & \\
\hline Smkoing & 6 & 12 \\
\hline Diabetes & 3 & 6 \\
\hline Cardiovascular disease & 1 & 20 \\
\hline Alcoholism & 2 & 4 \\
\hline Smoking + alcoholism & 13 & 26 \\
\hline Diabetes + alcoholism & 2 & 4 \\
\hline Diabetes + smoking & 2 & 4 \\
\hline $\begin{array}{l}\text { Others (loss of motor function and sensitivity, malnutrition, hypertension, fecal and } \\
\text { urinary incontinence, among others) }\end{array}$ & 21 & 42 \\
\hline $\begin{array}{l}\text { Number of injuries } \\
\text { Mean of PI per patient and standard deviation }\end{array}$ & $1.68 \pm 1.16$ & \\
\hline $\begin{array}{l}\text { One } \\
\end{array}$ & 35 & 70 \\
\hline Two & 3 & 6 \\
\hline Three & 7 & 14 \\
\hline Four & 3 & 6 \\
\hline Five & 2 & 4 \\
\hline \multicolumn{3}{|l|}{ Region in which the first PI occured } \\
\hline Occipital & 3 & 6 \\
\hline Sacral & 43 & 86 \\
\hline Calcaneal & 3 & 6 \\
\hline Other & 1 & 2 \\
\hline \multicolumn{3}{|l|}{ Presence of infected injury } \\
\hline Yes (all in sacral region) & 15 & 30 \\
\hline No & 35 & 70 \\
\hline
\end{tabular}

Fonte: Dados da pesquisa, 2019.

Table 5. Preventive care for PI and ND in patients with SCI provided by the nursing team in a reference hospital, from 2013 to 2016. Belém-PA, 2019.

\begin{tabular}{|c|c|c|c|c|c|}
\hline Preventive care & Freq. & $\%$ & Nursing diagnostics & Freq. & $\%$ \\
\hline Use of egg crate mattress & 50 & 100 & Impaired skin integrity & 50 & 100 \\
\hline Change of decubitus & 48 & 96 & Risk of infection & 50 & 100 \\
\hline Use of cushion & 40 & 80 & Impaired physical mobility & 50 & 100 \\
\hline Humidity-free patient maintenance & 40 & 80 & Risk of falling & 50 & 100 \\
\hline Use of barrier cream & 35 & 70 & Impaired mobility in bed & 45 & 90 \\
\hline Keep sheets dry and stretched & 34 & 68 & Acute pain & 44 & 88 \\
\hline Observe, note and report skin changes & 33 & 66 & Deficit in self-care for bath/hygiene & 42 & 84 \\
\hline Use of transparent films in prominence & 25 & 50 & Ineffective tissue perfusion & 38 & 76 \\
\hline \multirow[t]{3}{*}{ Intimate hygiene after evacuations } & 15 & 30 & Impaired comfort & 38 & 76 \\
\hline & & & Anxiety & 27 & 54 \\
\hline & & & Unbalanced nutrition, less than body needs & 10 & 20 \\
\hline
\end{tabular}

Source: Research data, 2019. 
15 patients (30\%) of the total of medical records analyzed presented infected PI, all in the sacral region.

Table 5 shows the preventive care provided by the nursing team to patients with SCI. From the 50 (100\%) medical records analyzed, it was identified as priority care: installation of egg crate mattress (100\%), change of decubitus (96\%), use of cushions and maintenance of the patient free of moisture (80\%), as prevention to PIs.

The nursing diagnoses (ND) established for patients with post-SCI LP are also described. It was evidenced that about $100 \%$ of the sample had: impaired skin integrity, risk of infection, impaired physical mobility and risk of falling.

\section{DISCUSSION}

This study evidenced the PI as one of the complications developed by patients with SCI, considering that the spinal cord injury is one of the most serious complications that causes disability to humans, compromising vital functions, including locomotion and loss of sensitivity. Similar studies address the prevalence of PI in these patients and that the appearance of PI in patients with spinal cord injury strongly impacts the quality of life of these people $\mathrm{e}^{7,8}$.

The affliction of SCI in men is still bigger than in women, as in research similar to this study. This profile may be related to lifestyle, as men exhibit challenging behavior by exposing themselves more to risky occasions?.

Regarding other sociodemographic variables of patients with SCI, were found patients aged around 37 years, from the metropolitan area or interior of the state, with mean hospitalization time over 60 days due to complications, among them the $\mathrm{PI}^{10}$. Also, regarding the origin of the patients, it is worth mentioning that Pereira, Gomes and Rodrigues reported in a similar study that many of the patients are transferred to large cities, due to the lack of structure and beds for treatment of polytraumatized patients ${ }^{10}$.

It is important to point out that the death rate in this study was not high, thus, patients who received improved discharge and returned to their homes with some type of special permanent need, therefore, will sometimes need specialized care, not feasible in view of the social condition or the absence of reference and rehabilitation services ${ }^{10,11}$.
The most affected medullar segments are the cervical and thoracic regions, caused by firearm accidents, followed by accidents caused by falls and diving in shallow water ${ }^{10,12,13}$, corroborating the findings of this research. The total medullary trauma of the cervical segment and the initial part of the thoracic spine may result in quadriplegia and, in other situations, the partial dissection of other parts of the spine will result in paraplegia as a sequel, according to this investigation and the analyzed study ${ }^{14}$.

The development of a PI is multifactorial and most patients with SCI, who are critical, evolve with hemodynamic instability and impaired mobility that restricts them to the bed, which favors the development of PI. Some authors show that critically ill patients present some risk for the development of PI after 2 or 3 days ${ }^{15}$.

Patient safety is directly related to the reduction of risks and avoidable damages to the minimum possible in healthcare, therefore, the increase in hospitalization time results in skin lesions, considered a serious and worrisome health problem. In addition, the occurrence of PI in the hospital environment is considered an adverse event and may portray the quality of care provided by the health institution ${ }^{16,17}$.

Regarding the number of PI presented per patient, the literature indicates that the mean is 1.85 lesions per patient, predominantly in the sacral and trochanter regions, a fact evidenced in our study, where most patients presented PI in the sacral region. This is justified by the functionality of the patient's support bone structures, whether seated or in horizontal or lateral dorsal decubitus, as well as the interface of these long bones with numerous muscles ${ }^{18}$.

Pressure injury prevention has been considered a quality indicator not only of the health unit/service, but also of nursing care. Because of this, the nursing team has implemented preventive PI interventions, although its multicausality is recognized. The literature highlights that the systematic implementation of best practices recommended in the guidelines for clinical practice has been a challenge for many institutions ${ }^{19}$.

The prevention measures do not differ much from those found in this study, but they encourage rethinking the nursing care practice, which should be based on scientific events that reflect on patient care.

In Brazil, a study conducted to verify the occurrence of PI in patients with spinal cord injury emphasized the interventions for prevention. This same concern is also punctuated by nurses 
when considering the nursing process focused on the clinical view of the patient as essential, with regard to prevention and care specifically aimed at patients with $\mathrm{PI}^{20,21}$.

As limitations of the study, the authors had the minimum time provided by the health institution for data collection and the lack of coherent information regarding the diagnosis of SCI and the time of appearance of PI in patients.

\section{CONCLUSION}

The research provided knowledge of the profile of patients with spinal cord injury (SCI) who developed pressure injury (PI) during the period of hospitalization in a reference hospital located in the metropolitan region of Belém-Pará, showing that the majority of SCI victims are male, who were hospitalized on average 66 days, had firearm accidents and falls, respectively, as etiology of spinal cord injury. However, the vast majority received improved discharge, but presenting paraplegia as a permanent sequel.

The study also showed that the spinal cord level most affected by trauma were the thoracic and cervical regions. The mean time for the appearance of the first PI was 19 days, the majority of patients presented only one PI and the region sacral was the most frequently affected.
In addition, the preventive care listed by the nursing staff to patients with SCI was known as a way to reduce the risks of PI. In this context, it is important to emphasize the need for the engagement of the transdisciplinary team, the involvement of the leaders of health institutions, the training for the nursing professional and the team for skin care and treatment of PI when installed, as well as continuing education and feedback of the results achieved.

Therefore, the availability of data helped to demonstrate the occurrence of $\mathrm{PI}$ as a complication in patients with SCI during hospitalization, and may serve as a basis for the allocation of resources and preventive measures, as well as subsequent studies on the subject.

\section{AUTHORS' CONTRIBUTION}

Conceptualization, Santos FCS and Ramos AMPC; Methodology, Santos FCS and Ramos AMPC; Investigation, Santos FCS; Writing - Original Draft, Santos FCS; Souza MWO; Pereira AOV; Pimentel IMS and Ramos AMPC; Writing - Review and Editing, Santos FCS; Souza MWO; Pereira AOV; Pimentel IMS and Ramos AMPC; Resources, Santos FCS and Souza MWO; Supervision, Ramos AMPC.

\section{REFERENCES}

1. Soares CF, Heidemann ITSB. Promoção da saúde e prevenção da lesão por pressão: expectativas do enfermeiro da atenção primária. Texto Contexto Enferm. 2018;27(2):19. https://doi.org/10.1590/0104-070720180001630016

2. National Pressure Ulcer Advisory Panel-NPUAP. About us [Internet]. Washington: NPUAP; 2016: http://www.npuap. org/about-us/

3. Bomfim EO, Cabral DB, Júnior LCL, Santos MF, Cavalcante GM. Úlceras por pressão em pacientes com lesão medular traumática: subsídios na identificação microbiológica. J Res: Fundam Care Online 2014;6(2):747-58. https://doi. org/10.9789/2175-5361.2014v6n2p747

4. Rouanet C, Reges D, Rocha E, Gagliardi V, Silva GS. Traumatic spinal cord injury: current concepts and treatment update. Arq Neuropsiquiatr. 2017;75(6):387-93. https://doi. org/10.1590/0004-282X20170048

5. Lima AFC, Castilho V. Body mobilization for prevention of pressure ulcers: direct labor costs. Rev Bras Enferm. 2015;68(5):647-52. https://doi.org/10.1590/0034$7167.2015680523 i$
6. Mittag BF, Krause TCC, Roehrs H, Meier MJ, Danski MTR. Cuidados com lesão de pele: Ações da enfermagem. ESTIMA, Braz J Enterostomal Ther. 2017;15(1):19-25. https:// doi.org/10.5327/Z1806-3144201700010004

7. Zakrasek EC, Creasey G, Crew JD. Pressure ulcers in people with spinal cord injury in developing nations. Spinal Cord. 2015;53:7-13. https://doi.org/10.1038/sc.2014.179

8. Ministério da Saúde. Diretrizes de atenção ao lesado medular. 2 ed. Brasília (DF): Ministério da Saúde; 2015.

9. Bernardi DM. Epidemiologic profile of surgery for spinomedullary injury at a referral hospital in a country town of Brazil. Coluna/Columna. 2014;13(2):136-8. https:// doi.org/10.1590/S1808-18512014130200273

10. Pereira ELR, Gomes AL, Rodrigues DB. Epidemiologia do traumatismo Raquimedular por projéteis de armas de fogo em um hospital de referência no estado do Pará. Arq Bras Neurocir. 2015;34(1):13-9. https://doi. org/10.1055/s-0035-1547384

11. Carvajal C, Pacheco C, Gómez-Rojo C, Calderón J, Cadavid C, Jaimes F. Características clínicas y demográficas de 
pacientes con trauma Raquimedular Experiencia de seis años. Acta Med Colomb. 2015;40(1):45-50.

12. Silva OT, Ghizoni E, Tedeschi H, Joaquim AF. Epidemiology of spinal trauma surgically treated at the UNICAMP Hospital das Clínicas. Coluna/Columna. 2018;17(1):55-8. https://doi. org/10.1590/s1808-185120181701179262

13. Oliveira TAB, Andrade SMS, Prado GO, Fernandes RB, Gusmão MS, Gomes EGF, et al. Epidemiology of spine fractures in motorcycle accident victims. Coluna/Columna. 2016;15(1):65-67. https://doi.org/10.1590/S1808185120161501147147

14. Araujo AO, Ferronato DS, Rocha ID, Marcon RM, Alexandre CF, Filho TEPB. Profile of spinal cord trauma victims treated at a reference unit in São Paulo. Coluna/Columna. 2018;17(1):3941. https://doi.org/10.1590/S1808-185120181701178599

15. Otto C, Schumacher B, Wiese LPDL, Ferro C, Rodrigues RA. Fatores de risco para o desenvolvimento de lesão por pressão em pacientes críticos. Enferm Foco. 2019;10(1):0711. https://doi.org/10.21675/2357-707X.2019.v10.n1.1323
16. Martins M. Qualidade do cuidado em saúde. In: Sousa P, Mendes W, (Org.). Segurança do paciente: Conhecendo os riscos nas organizações de saúde. Rio de Janeiro (RJ): EAD/ ENSP; 2014. 25-38 p.

17. Fonseca $A D$, Peterlini $F L$, Costa DA, coordenadores. Segurança do paciente. São Paulo (SP): Martinari; 2014.

18. Mota, D, Barbosa Ribeiro, M. Calidad de vida en portadores de lesión medular con úlceras por presión. Enferm Glob. 2016;15(42):13-21.

19. Vasconcelos JMB, Caliri MHL. Ações de enfermagem antes e após um protocolo de prevenção de lesões por pressão em terapia intensiva. Esc Anna Nery. 2017;21(1):1-9. https://doi. org/10.5935/1414-8145.20170001

20. Andrade LT, Chianca TCM. Validação de intervenções de enfermagem para pacientes com lesão medular e mobilidade física prejudicada. Rev Bras Enferm. 2013;66(5):688-93. https://doi.org/10.1590/S0034-71672013000500008

21. Vasconcelos AS, França ISX, Sousa FS, Costa MML. Diagnósticos de enfermagem identificados no sujeito com lesão medular. J Nurs UFPE on-line. 7(5):1326-32. 